\title{
Development of Risk Evaluation and Mitigation Systems for Logistics System
}

\author{
Ahmad Rusdiansyah a, Della Deswiana Pratama a, Muhammad Faisal Ibrahim b* \\ a Department of Industrial Engineering, Institut Teknologi Sepuluh Nopember, Indonesia \\ Jl. ITS Raya, Keputih, Kec. Sukolilo, Kota SBY, Jawa Timur 60117, Indonesia \\ ${ }^{\mathrm{b}}$ Department of Logistics Engineering, Universitas Internasional Semen Indonesia, Indonesia \\ Jl. Veteran, Kb. Dalem, Sidomoro, Kebomas, Gresik Regency, East Java 61122, Indonesia \\ * Corresponding author: faisalibrahim.ie@gmail.com
}

\section{ARTICLE INFO}

Article history

Received December 30, 2019

Revised February 23, 2020

Accepted February 26, 2020

Available Online February 28, 2020

Keywords

Risk Management

Mitigations

Logistic

Risk evaluation

\section{ABSTRACT}

Logistic activities are significant activities that pose various risks for the company. These risks can affect the company's performance. To be able to compete in the globalization era, companies need proper risk management. This study aimed to develop Risk Evaluation and Mitigation Systems. We offered four stages: risk identification, risk analysis, risk evaluation, and risk response. A case study was conducted to implement the proposed Risk Evaluation and Mitigation Systems. The results indicated that the proposed Risk Evaluation and Mitigation Systems were proven to be appropriately applied to evaluate company risks and provide mitigation recommendations.

This is an open-access article under the $\mathrm{CC}-\mathrm{BY}$-SA license.

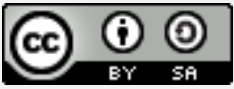

\section{Introduction}

Globalization forces companies to focus on company activities to face competition [1] [2]. One of the most critical company activities is a logistic activity [3] [4]. Good logistics management can increase customer satisfaction because the product, quality, quantity, and location shipped are correct [5]. In logistical activities, various risks often arise, and it affects supply chain performance [6] and risks arising from the impact of an event and uncertainty [7] [8]. Risk can disrupt the flow of material, information, and cash flow, which in turn can affect sales and increase costs [9]. To compete, companies need to have proper logistical risk management [10] [11]. Therefore, mitigation activities are needed to manage risks.

Several previous studies have proposed methods for managing supply chain risk. One popular method is the House of Risk (HOR) proposed by Pujawan and Laudine [12]. Several methods for supply chain risk management include the integration of the HOR and the Fuzzy Analytical Hierarchy Process [13], the HOR, and the Analytical network process [14], DEMATEL [15], and Quality Function Deployment (QFD) [16]. Several other methods are Fuzzy AHP [17], AHP [18], Fuzzy Bayesian-based Failure Mode Effect Analysis (FMEA) [19], and fuzzy-based HOR [20]. Wijai and Phongchai [21] used the HOR 
to analyze blood supply chain risk management. Ratnasari, et al. [22] analyze supply chain risk management in a newspaper company. Immawan and Putri [23] implement HOR to assess supply chain risk. Furthermore, Asbjørnslett [24] adopts a proactive approach to dealing with newly changing risks. Wee, et al. [25] discussed mitigation strategies in logical risk management from the perspective of process flow.

Based on previous research, one of the popular methods implemented in supply chain risk management is HOR. Unfortunately, the estimated loss and the possible risk have not been considered in assessing the risk. Therefore, this study aims to develop a Risk Evaluation and Mitigation System based on the HOR method. This study provides a new contribution to the Risk Evaluation and Mitigation System in company logistics activities. This complete paper structure is presented as follows: part 2 discusses Proposed Risk Evaluation and Mitigation Systems or Method and case studies; part 3 presents results and discussion, and lastly, part 4 concludes the study.

\section{Methods}

\subsection{Proposed Risk Evaluation and Mitigation Systems}

This research constructed four stages in the proposed Risk Evaluation and Mitigation Systems, such as risk identification, risk analysis, risk evaluation, and risk response (Fig. 1). The detailed description of each stage is explained as follows:

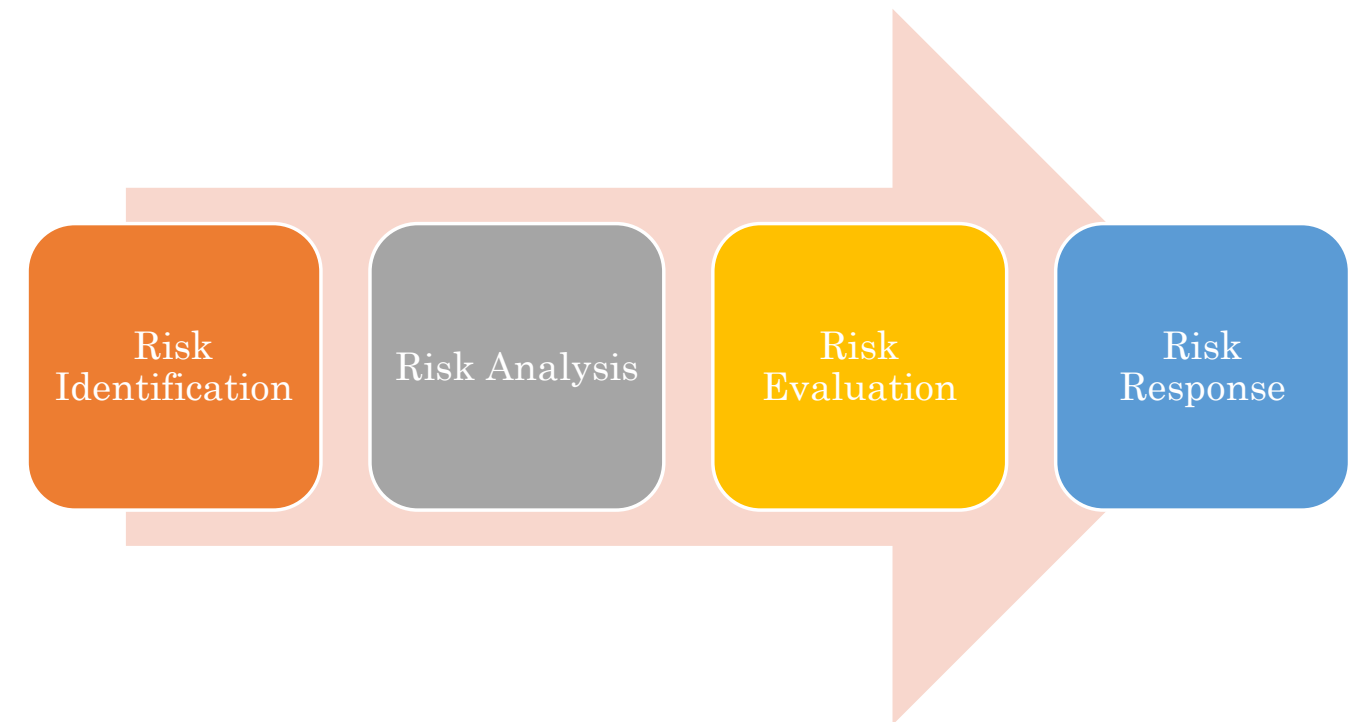

Fig. 1. Four Stages Risk Evaluation and Mitigation Systems

\section{Risk Identification}

At the risk identification stage, this study proposes risk identification based on the company's business process. Business processes were based on five business aspects: supplier, receiving, tracking, delivery, and customer. This business process is modified from the business aspects of the supplier, input, process, output, and customer. At this stage, each business process was recorded for risks, causes of risk, and impacts. The risk assessment is presented in the risk analysis section. 


\section{Risk Analysis}

At this stage, risk analysis was based on the Likelihood and Consequence values. Likelihood scores were obtained from the risk causes assessment based on five rating scales. The risk causes a likelihood scale is presented in Table 1. All risk causes at the risk identification stage were assessed for the Likelihood level of the risk causes. Consequently, this assessment was based on the value of the loss resulting from the impact of the risk. This study proposed a Consequence Assessment based on the losses resulting from the impact of the risk. All risk impacts were estimated by the amount of loss incurred.

Furthermore, the big loss was in conversion to the Consequence scale. This study suggested five Consequence Loss scales, which are presented in Table 2. The results of the Likelihood and Consequence assessment were used for the risk evaluation stage.

Table 1. Likelihood (L) Scale for risk causes

\begin{tabular}{|c|c|c|}
\hline Scale & Description & Parameter \\
\hline 5 & $\begin{array}{l}\text { Almost } \\
\text { Certain }\end{array}$ & $\begin{array}{l}\text { Mismatch always } \\
\text { occurs every } \\
\text { week }\end{array}$ \\
\hline 4 & Likely & $\begin{array}{l}\text { No-Mismatch } \\
\text { occurs within the } \\
\text { last } 1-2 \text { month(s) }\end{array}$ \\
\hline 3 & Possible & $\begin{array}{l}\text { No-Mismatch } \\
\text { occurs within the } \\
\text { last } 3-5 \text { months }\end{array}$ \\
\hline 2 & Unlikely & $\begin{array}{l}\text { No-Mismatch } \\
\text { occurs within the } \\
\text { last } 6 \text { - } 11 \text { months }\end{array}$ \\
\hline 1 & Rare & $\begin{array}{l}\text { No-Mismatch } \\
\text { occurs within the } \\
\text { last one year } \\
\text { period }\end{array}$ \\
\hline
\end{tabular}

Table 2. Consequence (C) Scale for risk effects

\begin{tabular}{lll}
\hline Scale & Description & Parameter \\
\hline 5 & Catastrophic & Loss $>$ IDR. \\
& & $1,000,000,000$ \\
4 & Major & Loss IDR. \\
& & $500,000,000-$ \\
& & IDR. \\
& & $1,000,000,000$ \\
3 & Moderate & Loss IDR. \\
& & $100,000,000-$ \\
& & IDR. \\
& & $500,000,000$ \\
2 & Minor & Loss IDR. \\
& & $10,000,000-$ \\
& & IDR. \\
& & $100,000,000$ \\
1 & Insignificant & Loss $<$ IDR. \\
& & $10,000,000$ \\
\end{tabular}

\section{Risk Evaluation}

Risk evaluation is a stage to evaluate the level of risk posed. At this stage, risk evaluation was based on calculating the Risk Priority Number (RPN). The RPN scores were generated from the Likelihood (L) and Consequence (C) assessments. The RPN formula is presented in Equation (1). Furthermore, this study projected five risk level categorization scales, which are presented in Table 3. RPN measured all risks to determine the level of risk. The RPN value was formed to calculate the mitigation priority presented in the risk response stage.

$$
R P N=L x C
$$

\section{Risk Response}

This stage described the mitigation proposals and calculated mitigation priorities. Mitigation proposals were designed based on the causes of risk. The list of mitigation proposals was used as input for the calculation of mitigation priorities. The mitigation priority calculation was modified from the House of Risk (HOR) model. The mitigation priority model can be seen in Table 4 . In the mitigation priority model, the value of the 
relationship between the causes of risk $\mathrm{j}$ and the mitigation action $\mathrm{k}$ is denoted as Ejk. The Ejk values used were $0,1,3$, and 9.0 indicated there was no relationship. 1 showed an innate but weak relationship between the causes of risk and the proposed mitigation. 3 represented a moderate relationship between the causes of risk and the proposed mitigation. Nine indicated that there was a strong relationship between the causes of risk and the proposed mitigation.

Table 3. Risk level scale based on RPN

Description
Very high
High
Moderate
Low
Very low

Parameter

RPN value of $21-25$

$\mathrm{RPN}$ value of $16-20$

RPN value of $11-15$

RPN value of $6-10$

RPN value of $1-5$

Furthermore, the RPN value of the risk cause $\mathrm{j}(\mathrm{RPNj})$ and Ejk was exemplified to calculate the Total Mitigation Effectiveness (TEM). The TEM formula is presented in Equation (2). Mitigation proposals were also assessed based on the level of difficulty (Dk). The mitigation Dk value showed the difficulty in mitigating due to unpredictable risks. This study exercised a Likert scale of 1 to 5 . The higher the Dk value, the more difficult mitigation was to be carried out. The value of Dk was utilized to calculate the effectiveness-difficulty mitigation ratio (EKM). The EKM formula for each mitigation is presented in Equation (3). Mitigation priorities were based on the order of the ECEC values from largest to smallest.

$$
\begin{aligned}
& T E M_{k}=\sum_{j} R P N_{j} E_{j k} \quad \forall k \\
& E K M_{k}=\frac{T E M_{k}}{D_{k}}
\end{aligned}
$$

\begin{tabular}{|c|c|c|c|c|c|c|c|c|c|}
\hline \multirow{2}{*}{ Cause Code } & \multirow{2}{*}{ Risk Cause (j) } & \multicolumn{7}{|c|}{ Mitigation Code (k) } & \multirow{2}{*}{$\begin{array}{c}\mathrm{RPN} \\
(\mathrm{j})\end{array}$} \\
\hline & & M1 & M2 & M3 & M4 & $\ldots$ & $\ldots$ & $\mathrm{Mk}$ & \\
\hline 1 & Cause 1 & $\mathrm{E}_{11}$ & $\mathrm{E}_{12}$ & $\mathrm{E}_{13}$ & $\mathrm{E}_{14}$ & $\ldots$ & $\ldots$ & $\mathrm{E}_{1 \mathrm{k}}$ & $\mathrm{RPN}_{1}$ \\
\hline 2 & Cause 2 & $\mathrm{E}_{21}$ & $\mathrm{E}_{22}$ & $\mathrm{E}_{23}$ & $\mathrm{E}_{24}$ & $\ldots$ & $\ldots$ & $\mathrm{E}_{2 \mathrm{k}}$ & $\mathrm{RPN}_{2}$ \\
\hline ... & $\ldots$ & $\ldots$ & $\ldots$ & $\ldots$ & $\ldots$ & $\ldots$ & $\ldots$ & $\ldots$ & $\ldots$ \\
\hline $\mathrm{j}$ & Cause j & $\mathrm{E}_{\mathrm{j} 1}$ & $\mathrm{E}_{\mathrm{j} 2}$ & $\mathrm{E}_{\mathrm{j} 3}$ & $\mathrm{E}_{\mathrm{j} 4}$ & $\ldots$ & $\ldots$ & $\mathrm{E}_{\mathrm{jk}}$ & $\mathrm{RPN}_{\mathrm{j}}$ \\
\hline \multicolumn{2}{|c|}{ Total mitigation effectiveness } & $T E M_{1}$ & $T E M_{2}$ & $\mathrm{TEM}_{3}$ & $\mathrm{TEM}_{4}$ & $\ldots$ & $\ldots$ & $T E M_{k}$ & \\
\hline \multirow{2}{*}{\multicolumn{2}{|c|}{$\begin{array}{c}\text { Mitigation difficulty } \\
\text { Mitigation effectiveness-difficulty } \\
\text { ratio }\end{array}$}} & $\mathrm{D}_{1}$ & $\mathrm{D}_{2}$ & $\mathrm{D}_{3}$ & $\mathrm{D}_{4}$ & $\ldots$ & $\ldots$ & $\mathrm{D}_{\mathrm{k}}$ & \\
\hline & & $E K M_{1}$ & $E K M_{2}$ & $E K M_{3}$ & $E K M_{4}$ & $\ldots$ & $\cdots$ & $E K M_{k}$ & \\
\hline \multicolumn{2}{|c|}{ Mitigation priority ranking } & & & & & $\ldots$ & $\ldots$ & & \\
\hline
\end{tabular}

Table 4. Mitigation Priority Calculation Model 


\subsection{A Case Study}

A case study was conducted in a chemical and pharmaceutical company in Indonesia to apply the proposed Risk Evaluation and Mitigation Systems. The logistics activities of the company were the focus of the problem in this study. Currently, the company's logistics activities were carried out internally. However, the company planned to transfer all logistics management to a third party (Third-party logistics (3PL)). Three 3PL candidates need to be considered in logistics management. The company also tries to overcome logistics management through internal companies. Therefore, it is necessary to evaluate risks and determine mitigation priorities in managing logistics in this company.

\section{Results and Discussion}

The four stages of risk evaluation and determining mitigation priorities are described in the following sub-sections.

\subsection{Risk Identification}

Risk identification was performed in the logistics department, referred to as the supplier, receiving, tracking, delivery, and customer business processes. The results of risk identification, causes of risk, and impacts can be seen in Table 5. Thirty-three (33) risks were collected for this problem. Furthermore, these 33 risks identified the causes of the risks and the impacts of the risks. There were 33 causes of risk and 29 impacts that result from the generated risks.

\subsection{Risk Analysis}

At this stage, thirty-three (33) causes of risk were successfully assessed based on the Likelihood scale. The results of the likelihood assessment can be seen in Table 6 . There were five causes of risk with a likelihood scale of 1 , eleven risk causes with a likelihood scale of 2 , and four risk causes with a likelihood scale of 3 . For the 4 and 5 likelihood scales, the number of causes was eight and one, respectively. These results indicate that the likeliness and likely scale will be the dominant scale on the Likelihood assessment.

Also, the Consequence assessment was delivered based on the estimated loss of company profit. The company loss was successfully estimated for 33 impact risks. The estimation results can be observed in Table 6 . The results indicated ten impacts with a consequence scale value of 1 , two impacts with a consequence scale value of 2 , eight impacts with a consequence scale value of 3 , and nine impacts with a consequence scale value of 4 . Likelihood and Consequence assessment results were generated as a risk evaluation calculation presented in the risk evaluation sub-section.

\subsection{Risk Evaluation}

Risk evaluation was underpinned from the level of risk classified based on the RPN. The results of the risk level can be seen in Table 6 . It can be seen that five risks were in a low category, 14 risks were in the very low category, five risks were in the medium category, and the other five risks were in the high category. These results were utilized as the basis for proposing company mitigation. 
Table 5. Risk identification

\begin{tabular}{|c|c|c|c|c|}
\hline $\begin{array}{l}\text { Risk } \\
\text { No }\end{array}$ & $\begin{array}{l}\text { Business } \\
\text { Process }\end{array}$ & Risk Name & Risk Cause & Impact \\
\hline 1 & Supplier & $\begin{array}{l}\text { Purchase Order (PO) failed } \\
\text { to be inputted }\end{array}$ & $\begin{array}{l}\text { PO was not listed in the } \\
\text { delivery request letter }\end{array}$ & $\begin{array}{l}\text { The acceptance process is } \\
\text { delayed, so that product } \\
\text { rejection occurs }\end{array}$ \\
\hline 2 & Supplier & $\begin{array}{l}\text { The product could not be } \\
\text { disassembled }\end{array}$ & $\begin{array}{l}\text { PO was not in line with } \\
\text { the goods }\end{array}$ & $\begin{array}{l}\text { Product availability } \\
\text { distraction }\end{array}$ \\
\hline 3 & Supplier & $\begin{array}{l}\mathrm{RM} \text { failed to be inputted } \\
\text { into the system }\end{array}$ & $\begin{array}{c}\text { CoA (Certificate of } \\
\text { Analysis) document was } \\
\text { not available }\end{array}$ & $\begin{array}{c}\text { The acceptance process is } \\
\text { delayed, so that product } \\
\text { rejection occurs }\end{array}$ \\
\hline 4 & Receiving & $\begin{array}{c}\text { The receipt was less than } \\
\text { the delivery request } \\
\text { order/letter }\end{array}$ & $\begin{array}{l}\text { Quantity did not match } \\
\text { with the delivery request } \\
\text { order/letter }\end{array}$ & $\begin{array}{l}\text { RM availability } \\
\text { distraction }\end{array}$ \\
\hline 5 & Receiving & $\begin{array}{l}\text { Mismatching Inventory per } \\
\text { batch }\end{array}$ & $\begin{array}{l}\text { Material mix in one } \\
\text { palette batch }\end{array}$ & $\begin{array}{c}\text { Delayed acceptance } \\
\text { process, so that the RM } \\
\text { was rejected }\end{array}$ \\
\hline 6 & Racking & $\begin{array}{c}\text { There was a difference in } \\
\text { PO receipts }\end{array}$ & $\begin{array}{l}\text { Wrong entry of the PO's } \\
\text { number }\end{array}$ & $\begin{array}{l}\text { Failure to detect the } \\
\text { number of inventory }\end{array}$ \\
\hline 7 & Racking & $\begin{array}{l}\text { There was a difference in } \\
\text { PO receipts }\end{array}$ & Wrong item entry & $\begin{array}{l}\text { number of inventory, RM } \\
\text { could not be used } \\
\text { immediately }\end{array}$ \\
\hline 8 & Racking & Mismatch PO Outstanding & $\begin{array}{l}\text { Wrong number of goods } \\
\text { entry }\end{array}$ & $\begin{array}{l}\text { Failure to detect the } \\
\text { number of inventory }\end{array}$ \\
\hline 9 & Racking & Inventory mismatch & Wrong batch entry & $\begin{array}{c}\text { The disruption of certain } \\
\text { RM availability }\end{array}$ \\
\hline 10 & Receiving & $\begin{array}{l}\text { Overloading of stored Raw } \\
\text { Material (RM) }\end{array}$ & $\begin{array}{c}\text { Transfer of RM } \\
\text { placement from another } \\
\text { Plant }\end{array}$ & $\begin{array}{c}\text { Additional warehouse } \\
\text { rental costs }\end{array}$ \\
\hline 11 & Supplier & $\begin{array}{c}\text { PO failed to be inputted into } \\
\text { the system }\end{array}$ & $\begin{array}{l}\mathrm{PO} \text { was not listed in the } \\
\text { delivery request letter }\end{array}$ & $\begin{array}{l}\text { The acceptance process is } \\
\text { delayed, so that product } \\
\text { rejection occurs }\end{array}$ \\
\hline 12 & Supplier & $\begin{array}{l}\text { The product could not be } \\
\text { disassembled }\end{array}$ & $\begin{array}{l}\text { PO was not in line with } \\
\text { the goods }\end{array}$ & $\begin{array}{l}\text { Product availability } \\
\text { distraction }\end{array}$ \\
\hline 13 & Supplier & $\begin{array}{l}\text { RM failed to be inputted } \\
\text { into the system }\end{array}$ & $\begin{array}{c}\text { CoA (Certificate of } \\
\text { Analysis) document was } \\
\text { not available }\end{array}$ & $\begin{array}{l}\text { The acceptance process is } \\
\text { delayed, so that product } \\
\text { rejection occurs }\end{array}$ \\
\hline 14 & Receiving & $\begin{array}{c}\text { The receipt was less than } \\
\text { the delivery request } \\
\text { order/letter }\end{array}$ & $\begin{array}{l}\text { Quantity did not match } \\
\text { with the delivery request } \\
\text { order/letter }\end{array}$ & $\begin{array}{l}\text { RM availability } \\
\text { distraction }\end{array}$ \\
\hline 15 & Receiving & $\begin{array}{l}\text { Mismatching Inventory per } \\
\text { batch }\end{array}$ & $\begin{array}{l}\text { Material mix in one } \\
\text { palette batch }\end{array}$ & $\begin{array}{c}\text { Delayed acceptance } \\
\text { process, so that the RM } \\
\text { was rejected }\end{array}$ \\
\hline 16 & Racking & $\begin{array}{c}\text { There was a difference in } \\
\text { PO receipts }\end{array}$ & $\begin{array}{l}\text { Wrong entry of the PO's } \\
\text { number }\end{array}$ & $\begin{array}{l}\text { Failure to detect the } \\
\text { number of inventory } \\
\text { Failure to detect the }\end{array}$ \\
\hline 17 & Racking & $\begin{array}{c}\text { There was a difference in } \\
\text { PO receipts }\end{array}$ & Wrong item entry & $\begin{array}{l}\text { number of inventory, RM } \\
\text { could not be used } \\
\text { immediately }\end{array}$ \\
\hline 18 & Racking & Mismatch PO Outstanding & $\begin{array}{l}\text { Wrong number of goods } \\
\text { entry }\end{array}$ & $\begin{array}{l}\text { Failure to detect the } \\
\text { number of inventory }\end{array}$ \\
\hline
\end{tabular}


Table 5. Risk identification (Continue)

\begin{tabular}{|c|c|c|c|c|}
\hline $\begin{array}{l}\text { Risk } \\
\text { No }\end{array}$ & $\begin{array}{l}\text { Business } \\
\text { Process }\end{array}$ & Risk Name & Risk Cause & Impact \\
\hline 19 & Racking & Inventory mismatch & Wrong batch entry & $\begin{array}{l}\text { The disruption of certain } \\
\text { RM availability }\end{array}$ \\
\hline 20 & Receiving & $\begin{array}{l}\text { Overloading of stored Raw } \\
\text { Material (RM) }\end{array}$ & $\begin{array}{c}\text { Transfer of RM } \\
\text { placement from another } \\
\text { Plant }\end{array}$ & - \\
\hline 21 & Delivery & $\begin{array}{c}\text { Could not send Finish } \\
\text { Goods (FG) to an external } \\
\text { warehouse }\end{array}$ & $\begin{array}{l}\text { Transporter could not } \\
\text { provide a fleet for } \\
\text { transportation }\end{array}$ & $\begin{array}{c}\text { FG stacking at the plant, } \\
\text { the availability of FG in } \\
\text { the shipping warehouse is } \\
\text { less }\end{array}$ \\
\hline 22 & Racking & $\begin{array}{l}\text { Lack of FG for order } \\
\text { fulfillment }\end{array}$ & $\begin{array}{l}\text { Delay in sending FG to } \\
\text { an external warehouse }\end{array}$ & - \\
\hline 23 & Racking & $\begin{array}{c}\text { There was a difference } \\
\text { between the FG recorded } \\
\text { and the external warehouse } \\
\text { receipts }\end{array}$ & $\begin{array}{l}\text { Wrong recording of the } \\
\text { number of items }\end{array}$ & - \\
\hline 24 & Racking & $\begin{array}{c}\text { Additional operator working } \\
\text { hours }\end{array}$ & $\begin{array}{l}\text { There were so many } \\
\text { orders at once }\end{array}$ & $\begin{array}{c}\text { Additional labor costs for } \\
\text { overtime }\end{array}$ \\
\hline 25 & Delivery & $\begin{array}{l}\text { Delivery could not be done } \\
\text { immediately, it had to be } \\
\text { verified first }\end{array}$ & $\begin{array}{c}\text { The type, quantity, and } \\
\text { batch number of goods } \\
\text { did not match the Picking } \\
\text { Note document }\end{array}$ & $\begin{array}{l}\text { Additional working hours } \\
\text { to re-check, late delivery } \\
\text { of FG }\end{array}$ \\
\hline 26 & Delivery & $\begin{array}{l}\text { Delivery could not be done } \\
\text { immediately, it had to be } \\
\text { verified first }\end{array}$ & $\begin{array}{l}\text { The type, quantity, and } \\
\text { batch number of goods } \\
\text { did not match the Picking } \\
\text { Note document }\end{array}$ & $\begin{array}{l}\text { Additional working hours } \\
\text { for rechecking, Delivery } \\
\text { Order (DO) could not be } \\
\text { issued immediately }\end{array}$ \\
\hline 27 & Customer & $\begin{array}{l}\text { Could not be sent } \\
\text { immediately on the date of } \\
\text { request }\end{array}$ & $\begin{array}{l}\text { There were so many } \\
\text { orders at once }\end{array}$ & $\begin{array}{l}\text { Delay or the cancellation } \\
\text { of FG delivery }\end{array}$ \\
\hline 28 & Customer & $\begin{array}{l}\text { Could not be sent } \\
\text { immediately due to waiting } \\
\text { for additional goods }\end{array}$ & $\begin{array}{l}\text { The volume of goods to be } \\
\text { loaded was very small, } \\
\text { not even one truck }\end{array}$ & $\begin{array}{l}\text { Delay or the cancellation } \\
\text { of FG delivery }\end{array}$ \\
\hline 29 & Delivery & $\begin{array}{l}\text { Could not send orders that } \\
\text { had been made }\end{array}$ & $\begin{array}{l}\text { Transporter could not } \\
\text { provide a fleet for } \\
\text { transportation }\end{array}$ & Delay of FG delivery \\
\hline 30 & Delivery & $\begin{array}{l}\text { Goods sent did not match } \\
\text { the request }\end{array}$ & $\begin{array}{l}\text { Items required were } \\
\text { damaged in packaging }\end{array}$ & $\begin{array}{l}\text { Addition of new packaging } \\
\text { costs, delay of FG delivery }\end{array}$ \\
\hline 31 & Delivery & Goods could not be sent & $\begin{array}{l}\text { Items dropped and } \\
\text { packaging damaged } \\
\text { during the transfer }\end{array}$ & $\begin{array}{l}\text { Addition of new packaging } \\
\text { costs, delays to } \\
\text { cancellation of } \mathrm{FG} \\
\text { shipments }\end{array}$ \\
\hline 32 & Delivery & $\begin{array}{l}\text { Some Pallet batches } \\
\text { remained unsent }\end{array}$ & $\begin{array}{l}\text { Delivery did not match } \\
\text { DO }\end{array}$ & - \\
\hline 33 & Delivery & $\begin{array}{l}\text { Could not be sent } \\
\text { immediately on the date of } \\
\text { request }\end{array}$ & $\begin{array}{l}\text { There were so many } \\
\text { orders at once }\end{array}$ & $\begin{array}{l}\text { Delay or the cancellation } \\
\text { of FG delivery }\end{array}$ \\
\hline
\end{tabular}

\subsection{Risk Response}

Based on risk evaluation, this study proposes 14 mitigation (Ms) proposals as follows: M1 is a reminder to suppliers to include clear and correct data. M2 is a check to the supplier so that the COA is also included. M3 is a Daily Cycle Count of materials regularly and consistently. M4 is an additional lease for the external warehouse. M5 is to make sure every delivery route has a backup transporter. M6 contains a request to Customer Service so that it can issue orders gradually. M7 is for warehouse operators to 
recalculate the number of items entered. M8 contains the instruction on checking the amount of cargo and clarification to the truck fleet drivers. M9 explains that every small order in number will be sent by Less Container Loaded (LCL). The M10 contains the identification and repair of defective items as soon as they are found. M11 suggests that forklift operators do movements to carry goods at low speed. M12 is the use of 3PLcompany 1. M13 contains the use of 3PL-company 2, and M14 describes the use of 3PLcompany 3 .

Table 6. Assessment of Likelihood, Consequence, RPN, and Level of Risk

\begin{tabular}{|c|c|c|c|c|c|c|c|}
\hline $\begin{array}{l}\text { Risk } \\
\text { No. }\end{array}$ & Risk Cause & $\mathrm{L}$ & Impact & $\begin{array}{l}\text { Estimated } \\
\text { Loss }\end{array}$ & $\mathrm{C}$ & RPN & Risk Level \\
\hline 1 & $\begin{array}{l}\text { PO was not listed } \\
\text { in the delivery } \\
\text { request letter }\end{array}$ & 2 & $\begin{array}{l}\text { The acceptance process } \\
\text { is delayed, so that } \\
\text { product rejection occurs }\end{array}$ & $\begin{array}{c}\text { IDR } \\
100,000,000\end{array}$ & 3 & 6 & Low \\
\hline 2 & $\begin{array}{l}\text { PO was not in-line } \\
\text { with goods }\end{array}$ & 2 & $\begin{array}{l}\text { Product availability } \\
\text { distraction }\end{array}$ & $\begin{array}{c}\text { IDR } \\
500,000,000\end{array}$ & 4 & 8 & Low \\
\hline 3 & $\begin{array}{l}\text { CoA (Certificate of } \\
\text { Analysis) } \\
\text { document was not } \\
\text { available }\end{array}$ & 4 & $\begin{array}{l}\text { The acceptance process } \\
\text { is delayed, so that } \\
\text { product rejection occurs }\end{array}$ & $\begin{array}{c}\text { IDR } \\
100,000,000\end{array}$ & 3 & 12 & Moderate \\
\hline 4 & $\begin{array}{l}\text { Quantity did not } \\
\text { match with the } \\
\text { delivery request } \\
\text { order/letter }\end{array}$ & 1 & $\begin{array}{l}\mathrm{RM} \text { availability } \\
\text { distraction }\end{array}$ & $\begin{array}{c}\text { IDR } \\
100,000,000\end{array}$ & 3 & 3 & Very Low \\
\hline 5 & $\begin{array}{l}\text { Material mix in } \\
\text { one palette batch }\end{array}$ & 2 & $\begin{array}{l}\text { Delayed acceptance } \\
\text { process, so that the RM } \\
\text { was rejected }\end{array}$ & $\begin{array}{c}\text { IDR } \\
50,000,000\end{array}$ & 2 & 4 & Very Low \\
\hline 6 & $\begin{array}{l}\text { Wrong entry of the } \\
\text { PO's number }\end{array}$ & 2 & $\begin{array}{l}\text { Failure to detect the } \\
\text { number of inventory }\end{array}$ & IDR & 1 & 2 & Very Low \\
\hline 7 & Wrong item entry & 1 & $\begin{array}{l}\text { Failure to detect the } \\
\text { number of inventory, } \\
\text { RM could not be used } \\
\text { immediately }\end{array}$ & $\begin{array}{l}\text { IDR } \\
-\end{array}$ & 1 & 1 & Very Low \\
\hline 8 & $\begin{array}{l}\text { Wrong number of } \\
\text { goods entry }\end{array}$ & 3 & $\begin{array}{l}\text { Failure to detect the } \\
\text { number of inventory }\end{array}$ & IDR & 1 & 3 & Very Low \\
\hline 9 & Wrong batch entry & 2 & $\begin{array}{l}\text { The disruption of } \\
\text { certain RM availability }\end{array}$ & $\begin{array}{l}\text { IDR } \\
-\end{array}$ & 1 & 2 & Very Low \\
\hline 10 & $\begin{array}{l}\text { Transfer of RM } \\
\text { placement from } \\
\text { another Plant }\end{array}$ & 2 & $\begin{array}{l}\text { Additional warehouse } \\
\text { rental costs }\end{array}$ & $\begin{array}{c}\text { IDR } \\
182,000,000\end{array}$ & 3 & 6 & Low \\
\hline 11 & $\begin{array}{l}\text { PO was not listed } \\
\text { in the delivery } \\
\text { request letter }\end{array}$ & 2 & $\begin{array}{l}\text { The acceptance process } \\
\text { is delayed, so that } \\
\text { product rejection occurs }\end{array}$ & $\begin{array}{c}\text { IDR } \\
100,000,000\end{array}$ & 3 & 6 & Low \\
\hline 12 & $\begin{array}{l}\text { PO was not in line } \\
\text { with the goods }\end{array}$ & 2 & $\begin{array}{l}\text { Product availability } \\
\text { distraction }\end{array}$ & $\begin{array}{c}\text { IDR } \\
500,000,000\end{array}$ & 4 & 8 & Low \\
\hline 13 & $\begin{array}{l}\text { CoA (Certificate } \\
\text { of Analysis) } \\
\text { document was not } \\
\text { available }\end{array}$ & 4 & $\begin{array}{l}\text { The acceptance process } \\
\text { is delayed, so that } \\
\text { product rejection occurs }\end{array}$ & $\begin{array}{c}\text { IDR } \\
100,000,000\end{array}$ & 3 & 12 & Moderate \\
\hline 14 & $\begin{array}{l}\text { Quantity did not } \\
\text { match with the } \\
\text { delivery request } \\
\text { order/letter }\end{array}$ & 1 & $\begin{array}{l}\text { RM availability } \\
\text { distraction }\end{array}$ & $\begin{array}{c}\text { IDR } \\
100,000,000\end{array}$ & 3 & 3 & Very Low \\
\hline
\end{tabular}


Table 6. Assessment of Likelihood, Consequence, RPN, and Level of Risk (Continue)

\begin{tabular}{|c|c|c|c|c|c|c|c|}
\hline $\begin{array}{l}\text { Risk } \\
\text { No. }\end{array}$ & Risk Cause & $\mathrm{L}$ & Impact & $\begin{array}{l}\text { Estimated } \\
\text { Loss }\end{array}$ & $\mathrm{C}$ & $\mathrm{RPN}$ & Risk Level \\
\hline 15 & $\begin{array}{l}\text { Material mix in } \\
\text { one palette batch }\end{array}$ & 2 & $\begin{array}{l}\text { Delayed acceptance } \\
\text { process, so that the RM } \\
\text { was rejected }\end{array}$ & $\begin{array}{c}\text { IDR } \\
50,000,000\end{array}$ & 2 & 4 & Very Low \\
\hline 16 & $\begin{array}{l}\text { Wrong entry of the } \\
\text { PO's number }\end{array}$ & 2 & $\begin{array}{l}\text { Failure to detect the } \\
\text { number of inventory }\end{array}$ & $\begin{array}{c}\text { IDR } \\
-\end{array}$ & 1 & 2 & Very Low \\
\hline 17 & Wrong item entry & 1 & $\begin{array}{l}\text { Failure to detect the } \\
\text { number of inventory, } \\
\text { RM could not be used } \\
\text { immediately }\end{array}$ & $\begin{array}{c}\text { IDR } \\
-\end{array}$ & 1 & 1 & Very Low \\
\hline 18 & $\begin{array}{l}\text { Wrong number of } \\
\text { goods entry }\end{array}$ & 3 & $\begin{array}{l}\text { Failure to detect the } \\
\text { number of inventory }\end{array}$ & $\begin{array}{c}\text { IDR } \\
-\end{array}$ & 1 & 3 & Very Low \\
\hline 19 & Wrong batch entry & 2 & $\begin{array}{l}\text { The disruption of } \\
\text { certain RM availability }\end{array}$ & $\begin{array}{c}\text { IDR } \\
-\end{array}$ & 1 & 2 & Very Low \\
\hline 21 & $\begin{array}{l}\text { Transporter could } \\
\text { not provide a fleet } \\
\text { for transportation }\end{array}$ & 1 & $\begin{array}{l}\text { FG stacking at the } \\
\text { plant, the availability } \\
\text { of FG in the shipping } \\
\text { warehouse is less }\end{array}$ & $\begin{array}{c}\text { IDR } \\
-\end{array}$ & 1 & 1 & Very Low \\
\hline 24 & $\begin{array}{l}\text { There were so } \\
\text { many orders at } \\
\text { once }\end{array}$ & 5 & $\begin{array}{l}\text { Additional labor costs } \\
\text { for overtime }\end{array}$ & $\begin{array}{c}\text { IDR } \\
300,000,000\end{array}$ & 3 & 15 & Moderate \\
\hline 25 & $\begin{array}{l}\text { The type, } \\
\text { quantity, and } \\
\text { batch number of } \\
\text { goods did not } \\
\text { match the Picking } \\
\text { Note document }\end{array}$ & 4 & $\begin{array}{l}\text { Additional working } \\
\text { hours to re-check, late } \\
\text { delivery of FG }\end{array}$ & $\begin{array}{c}\text { IDR } \\
5,000,000\end{array}$ & 1 & 4 & Very Low \\
\hline 26 & $\begin{array}{l}\text { The type, } \\
\text { quantity, and } \\
\text { batch number of } \\
\text { goods did not } \\
\text { match the Picking } \\
\text { Note document }\end{array}$ & 3 & $\begin{array}{l}\text { Additional working } \\
\text { hours for rechecking, } \\
\text { Delivery Order (DO) } \\
\text { could not be issued } \\
\text { immediately }\end{array}$ & $\begin{array}{c}\text { IDR } \\
500,000,000\end{array}$ & 4 & 12 & Moderate \\
\hline 27 & $\begin{array}{l}\text { There were so } \\
\text { many orders at } \\
\text { once }\end{array}$ & 4 & $\begin{array}{l}\text { Delay or the } \\
\text { cancellation of FG } \\
\text { delivery }\end{array}$ & $\begin{array}{c}\text { IDR } \\
500,000,000\end{array}$ & 4 & 16 & High \\
\hline 28 & $\begin{array}{l}\text { The volume of } \\
\text { goods to be loaded } \\
\text { was very small, } \\
\text { not even one truck }\end{array}$ & 4 & $\begin{array}{l}\text { Delay or the } \\
\text { cancellation of FG } \\
\text { delivery }\end{array}$ & $\begin{array}{c}\text { IDR } \\
500,000,000\end{array}$ & 4 & 16 & High \\
\hline 29 & $\begin{array}{l}\text { Transporter could } \\
\text { not provide a fleet } \\
\text { for transportation }\end{array}$ & 4 & Delay of FG delivery & $\begin{array}{c}\text { IDR } \\
500,000,000\end{array}$ & 4 & 16 & High \\
\hline 30 & $\begin{array}{l}\text { Items required } \\
\text { were damaged in } \\
\text { packaging }\end{array}$ & 4 & $\begin{array}{l}\text { Addition of new } \\
\text { packaging costs, delay } \\
\text { of FG delivery }\end{array}$ & $\begin{array}{c}\text { IDR } \\
500,000,000\end{array}$ & 4 & 16 & High \\
\hline 31 & $\begin{array}{l}\text { Items dropped and } \\
\text { packaging } \\
\text { damaged during } \\
\text { the transfer }\end{array}$ & 3 & $\begin{array}{l}\text { Addition of new } \\
\text { packaging costs, delays } \\
\text { to cancellation of } \mathrm{FG} \\
\text { shipments }\end{array}$ & $\begin{array}{c}\text { IDR } \\
500,000,000\end{array}$ & 4 & 12 & Moderate \\
\hline 33 & $\begin{array}{l}\text { There were so } \\
\text { many orders at } \\
\text { once }\end{array}$ & 4 & $\begin{array}{l}\text { Delay or the } \\
\text { cancellation of FG } \\
\text { delivery }\end{array}$ & $\begin{array}{c}\text { IDR } \\
500,000,000\end{array}$ & 4 & 16 & High \\
\hline
\end{tabular}


Furthermore, from the 14 mitigation proposals, calculations were then carried out to determine mitigation priorities. The results of the calculation of mitigation priorities are presented in Fig. 2. These results indicated that the use of 3PL-company 1 (M12) has the highest priority, followed by the use of 3PL-company 2 (M13) and the warehouse operator recalculates the number of items entered (M7).

\begin{tabular}{|c|c|c|c|c|c|c|c|c|c|c|c|c|c|c|c|}
\hline \multirow{2}{*}{ Risk Cause } & \multicolumn{14}{|c|}{ Mitigation } & \multirow{2}{*}{$\begin{array}{c}\mathbf{R P} \\
\mathbf{N}\end{array}$} \\
\hline & M1 & M2 & M3 & M4 & M5 & M6 & M7 & M8 & M9 & M10 & M11 & M12 & M13 & M14 & \\
\hline PO was not listed in the delivery request letter & 1 & 0 & 0 & 0 & 0 & 0 & 0 & 0 & 0 & 0 & 0 & 0 & 0 & 0 & 6 \\
\hline PO was not in-line with goods & 1 & 0 & 0 & 0 & 0 & 0 & 0 & 0 & 0 & 0 & 0 & 0 & 0 & 0 & 8 \\
\hline CoA (Certificate of Analysis) document was not available & 0 & 3 & 0 & 0 & 0 & 0 & 0 & 0 & 0 & 0 & 0 & 0 & 0 & 0 & 12 \\
\hline Quantity did not match with the delivery request order/letter & 0 & 0 & 0 & 0 & 0 & 0 & 0 & 0 & 0 & 0 & 0 & 0 & 0 & 0 & 3 \\
\hline Material mix in one palette batch & 0 & 0 & 1 & 0 & 0 & 0 & 0 & 0 & 0 & 0 & 0 & 0 & 0 & 0 & 4 \\
\hline Wrong entry of the PO's number & 0 & 0 & 1 & 0 & 0 & 0 & 0 & 0 & 0 & 0 & 0 & 0 & 0 & 1 & 2 \\
\hline Wrong item entry & 0 & 0 & 1 & 0 & 0 & 0 & 0 & 0 & 0 & 0 & 0 & 0 & 0 & 1 & 1 \\
\hline Wrong number of goods entry & 0 & 0 & 1 & 0 & 0 & 0 & 0 & 0 & 0 & 0 & 0 & 0 & 0 & 1 & 3 \\
\hline Wrong batch entry & 0 & 0 & 1 & 0 & 0 & 0 & 0 & 0 & 0 & 0 & 0 & 0 & 0 & 1 & 2 \\
\hline Transfer of RM placement from another Plant & 0 & 0 & 0 & 1 & 0 & 0 & 0 & 0 & 0 & 0 & 0 & 0 & 0 & 1 & 6 \\
\hline PO was not listed in the delivery request letter & 1 & 0 & 0 & 0 & 0 & 0 & 0 & 0 & 0 & 0 & 0 & 0 & 0 & 0 & 6 \\
\hline PO was not in line with the goods & 1 & 0 & 0 & 0 & 0 & 0 & 0 & 0 & 0 & 0 & 0 & 0 & 0 & 0 & 8 \\
\hline CoA (Certificate of Analysis) document was not available & 0 & 3 & 0 & 0 & 0 & 0 & 0 & 0 & 0 & 0 & 0 & 0 & 0 & 0 & 12 \\
\hline Quantity did not match with the delivery request order/letter & 0 & 0 & 0 & 0 & 0 & 0 & 0 & 0 & 0 & 0 & 0 & 0 & 0 & 0 & 3 \\
\hline Material mix in one palette batch & 0 & 0 & 1 & 0 & 0 & 0 & 0 & 0 & 0 & 0 & 0 & 0 & 0 & 0 & 4 \\
\hline Wrong entry of the PO's number & 0 & 0 & 1 & 0 & 0 & 0 & 0 & 0 & 0 & 0 & 0 & 0 & 0 & 1 & 2 \\
\hline Wrong item entry & 0 & 0 & 1 & 0 & 0 & 0 & 0 & 0 & 0 & 0 & 0 & 0 & 0 & 1 & 1 \\
\hline Wrong number of goods entry & 0 & 0 & 1 & 0 & 0 & 0 & 0 & 0 & 0 & 0 & 0 & 0 & 0 & 1 & 3 \\
\hline Wrong batch entry & 0 & 0 & 1 & 0 & 0 & 0 & 0 & 0 & 0 & 0 & 0 & 0 & 0 & 1 & 2 \\
\hline Transporter could not provide a fleet for transportation & 0 & 0 & 0 & 0 & 1 & 0 & 0 & 0 & 0 & 0 & 0 & 1 & 1 & 1 & 1 \\
\hline There were so many orders at once & 0 & 0 & 0 & 0 & 0 & 3 & 0 & 0 & 0 & 0 & 0 & 3 & 3 & 3 & 15 \\
\hline $\begin{array}{l}\text { The type, quantity, and batch number of goods did not match } \\
\text { the Picking Note document }\end{array}$ & 0 & 0 & 0 & 0 & 0 & 0 & 1 & 0 & 0 & 0 & 0 & 1 & 1 & 1 & 4 \\
\hline $\begin{array}{l}\text { The type, quantity, and batch number of goods did not match } \\
\text { the Picking Note document }\end{array}$ & 0 & 0 & 0 & 0 & 0 & 0 & 0 & 3 & 0 & 0 & 0 & 3 & 3 & 3 & 12 \\
\hline There were so many orders at once & 0 & 0 & 0 & 0 & 0 & 9 & 0 & 0 & 0 & 0 & 0 & 9 & 9 & 9 & 16 \\
\hline $\begin{array}{l}\text { The volume of goods to be loaded was very small, not even one } \\
\text { truck }\end{array}$ & 0 & 0 & 0 & 0 & 0 & 0 & 0 & 0 & 9 & 0 & 0 & 9 & 9 & 9 & 16 \\
\hline Transporter could not provide a fleet for transportation & 0 & 0 & 0 & 0 & 9 & 0 & 0 & 0 & 0 & 0 & 0 & 9 & 9 & 9 & 16 \\
\hline Items required were damaged in packaging & 0 & 0 & 0 & 0 & 0 & 0 & 0 & 0 & 0 & 9 & 0 & 9 & 9 & 9 & 16 \\
\hline Items dropped and packaging damaged during the transfer & 0 & 0 & 0 & 0 & 0 & 0 & 0 & 0 & 0 & 0 & 3 & 3 & 3 & 3 & 12 \\
\hline There were so many orders at once & 0 & 0 & 0 & 0 & 0 & 9 & 0 & 0 & 0 & 0 & 0 & 9 & 9 & 9 & 16 \\
\hline Total mitigation effectiveness & 28 & 72 & 24 & 6 & 145 & 333 & 4 & 36 & 144 & 144 & 36 & 842 & 842 & 864 & \\
\hline Mitigation difficulty & 4 & 4 & 5 & 5 & 3 & 3 & 3 & 4 & 3 & 4 & 4 & 1 & 5 & 5 & \\
\hline Mitigation effectiveness-difficulty ratio & 7 & 18 & 4.8 & 1.2 & 48 & 111 & 1.3 & 9 & 48 & 36 & 9 & 842 & 168 & 173 & \\
\hline Mitigation priority ranking & 10 & 7 & 11 & 13 & 4 & 3 & 12 & 8 & 5 & 6 & 8 & 1 & 2 & 14 & \\
\hline
\end{tabular}

Fig. 2 Mitigation Priority Calculation

\section{Conclusion}

This study was projected to develop a Risk Evaluation and Mitigation System based on the HOR method. It succeeded in developing Risk Evaluation and Mitigation Systems. The case study results underlined that the proposed Risk Evaluation and Mitigation Systems could be appropriately applied to evaluate company risks and provide

Please cite this article as: Rusdiansyah, A., Pratama, D., \& Ibrahim, M. (2020). Development of Risk Evaluation and Mitigation Systems for Logistics System. Jurnal Teknik Industri, 21(1), 92-103. doi:https://doi.org/10.22219/JTIUMM.Vol21.No1.92-103 
mitigation recommendations. In this study, we ignored the interdependence of risks and between mitigations. In actual conditions, the dependence between risks and between mitigation is possible. Therefore, further studies should consider the interdependence factors of risks and mitigations.

\section{References}

[1] Ö. F. Gürcan, İ. Yazıcı, Ö. F. Beyca, Ç. Y. Arslan, and F. Eldemir, "Third Party Logistics (3PL) Provider Selection with AHP Application," Procedia - Social and Behavioral Sciences, vol. 235, pp. 226-234, 2016, https://dx.doi.org/10.1016/j.sbspro.2016.11.018.

[2] F. Ibrahim, "Integrated Supply Chain Contract Model With Drop-Shipper Players," Jurnal Teknik Industri, vol. 19, no. 1, pp. 58-72, 2018, https://dx.doi.org/10.22219/JTIUMM.Vol19.No1.58-72.

[3] A. Rusdiansyah and A. Aryusamalia, "Penentuan Jumlah dan Kombinasi Jenis Kendaraan dengan Saving Heuristik pada Perusahaan Jasa Logistik Pihak Ketiga," 2008, saving heuristic, consolidation delivery, service logistics third party vol. 8, no. 2, p. 7, 2008, https://dx.doi.org/10.22219/JTIUMM.Vol8.No2.172-178.

[4] P. S. Ceryno, L. F. Scavarda, and K. Klingebiel, "Supply chain risk: empirical research in the automotive industry," Journal of Risk Research, vol. 18, no. 9, pp. 1145-1164, 2015, https://dx.doi.org/10.1080/13669877.2014.913662.

[5] X. Li, "Operations Management of Logistics and Supply Chain: Issues and Directions," Discrete Dynamics in Nature and Society, vol. 2014, p. 701938, 2014, https://dx.doi.org/10.1155/2014/701938.

[6] M. Ulfah, M. S. Maarif, and S. R. Sukardi, "Analisis dan perbaikan manajemen risiko rantai pasok gula rafinasi dengan Pendekatan house of risk," Journal of Agroindustrial Technology, vol. 26, no. 1, 2016, https://journal.ipb.ac.id/index.php/jurnaltin/article/view/13129.

[7] P. Raj Sinha, E. Whitman Larry, and D. Malzahn, "Methodology to mitigate supplier risk in an aerospace supply chain," Supply Chain Management: An International Journal, vol. 9, no. 2, pp. 154-168, 2004, https://dx.doi.org/10.1108/13598540410527051.

[8] W. Ho, T. Zheng, H. Yildiz, and S. Talluri, "Supply chain risk management: a literature review," International Journal of Production Research, vol. 53, no. 16, pp. 5031-5069, 2015, https://dx.doi.org/10.1080/00207543.2015.1030467.

[9] S. Chopra and M. S. Sodhi. (2004) Managing Risk To Avoid Supply-Chain Breakdown. MIT Sloan Management Review. 53-61.

[10] C. Colicchia and F. Strozzi, "Supply chain risk management: a new methodology for a systematic literature review," Supply Chain Management: An International $\begin{array}{llllll}\text { Journal, } & \text { vol. } 17, \quad \text { no. 4, }\end{array}$ https://dx.doi.org/10.1108/13598541211246558.

[11] A. Ghadge, S. Dani, and R. Kalawsky, "Supply chain risk management: present and future scope," The International Journal of Logistics Management, vol. 23, no. 3, pp. 313-339, 2012, https://dx.doi.org/10.1108/09574091211289200.

[12] I. Nyoman Pujawan and H. Geraldin Laudine, "House of risk: a model for proactive supply chain risk management," Business Process Management Journal, vol. 15, no. 6, pp. 953-967, 2009, https://dx.doi.org/10.1108/14637150911003801.

[13] W. A. Teniwut, "Challenges in Reducing Seaweed Supply Chain Risks Arising Within and Outside Remote Islands in Indonesia: An Integrated MCDM

Please cite this article as: Rusdiansyah, A., Pratama, D., \& Ibrahim, M. (2020). Development of Risk Evaluation and Mitigation Systems for Logistics System. Jurnal Teknik Industri, 21(1), 92-103. 
Approach," in Sustainability Modeling in Engineering, pp. 271-291, 2020, https://doi.org/10.1142/9789813276338_0012.

[14] N. Ummi, P. Ferro Ferdinant, A. Irman M.S, and A. Gunawan, "Integration house of risk and analytical network process for supply chain risk mitigation of cassava opak chips industry," MATEC Web Conf., vol. 218, p. 04022, 2018, https://dx.doi.org/10.1051/matecconf/201821804022.

[15] K. Govindan and A. Chaudhuri, "Interrelationships of risks faced by third party logistics service providers: A DEMATEL based approach," Transportation Research Part E: Logistics and Transportation Review, vol. 90, pp. 177-195, 2016, https://dx.doi.org/10.1016/j.tre.2015.11.010.

[16] M. M. H. Chowdhury and M. A. Quaddus, "A multiple objective optimization based QFD approach for efficient resilient strategies to mitigate supply chain

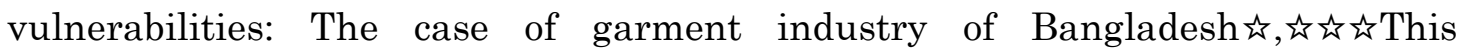
manuscript was processed by Associate Editor B. Lev," Omega, vol. 57, pp. 5-21, 2015, https://dx.doi.org/10.1016/j.omega.2015.05.016.

[17] K. Ganguly Kunal and K. Guin Kalyan, "A fuzzy AHP approach for inbound supply risk assessment," Benchmarking: An International Journal, vol. 20, no. 1, pp. 129146, 2013, https://dx.doi.org/10.1108/14635771311299524.

[18] N. Khalil, S. N. Kamaruzzaman, and M. R. Baharum, "Ranking the indicators of building performance and the users' risk via Analytical Hierarchy Process (AHP): Case of Malaysia," Ecological Indicators, vol. 71, pp. 567-576, 2016, https://dx.doi.org/10.1016/j.ecolind.2016.07.032.

[19] C. Wan, X. Yan, D. Zhang, Z. Qu, and Z. Yang, "An advanced fuzzy Bayesian-based FMEA approach for assessing maritime supply chain risks," Transportation Research Part E: Logistics and Transportation Review, vol. 125, pp. 222-240, 2019, https://dx.doi.org/10.1016/j.tre.2019.03.011.

[20] H.-L. Ma and C. Wong Wai-Hung, "A fuzzy-based House of Risk assessment method for manufacturers in global supply chains," Industrial Management \& Data Systems, vol. 118, no. 7, pp. 1463-1476, 2018, https://dx.doi.org/10.1108/IMDS-102017-0467.

[21] W. Boonyanusith and P. Jittamai, "Blood Supply Chain Risk Management using House of Risk Model," Walailak Journal of Science and Technology (WJST), vol. 16, no. 8, pp. 573-591, 2018, http://wjst.wu.ac.th/index.php/wjst/article/view/3472.

[22] S. Ratnasari, M. Hisjam, and W. Sutopo, "Supply chain risk management in newspaper company: House of risk approach," 2018, doi: https://dx.doi.org/10.1063/1.5024075.

[23] T. Immawan and D. K. Putri, "House of risk approach for assessing supply chain risk management strategies: A case study in Crumb Rubber Company Ltd," MATEC Web Conf., vol. 154, p. 01097, 2018. [Online]. Available: https://dx.doi.org/10.1051/matecconf/201815401097.

[24] B. E. Asbjørnslett, "Assessing the Vulnerability of Supply Chains," Supply Chain Risk: A Handbook of Assessment, Management, and Performance, pp. 15-33, 2009, https://dx.doi.org/10.1007/978-0-387-79934-6_2.

[25] H. M. Wee, M. F. Blos, and W.-H. Yang, "Risk management in logistics," in Handbook on Decision Making: Springer, 2012, pp. 285-305. 